\title{
EXAMINING A NEWS DISCOURSE OF A FEMALE POLITICIAN IN INDONESIA: FAIRCLOUGH'S MODEL OF CRITICAL DISCOURSE ANALYSIS AND ITS IMPLICATION IN ENGLISH LANGUAGE TEACHING
}

\author{
Wulandari Santoso* \\ English Language and Culture Department, Bunda Mulia University \\ Received on 25 September 2018 / Approved on 15 October 2018
}

\begin{abstract}
As one of the most important sites in which particular agenda are articulated and disseminated, news media play important roles in reproducing power relations and ideologies. Drawing on Fairclough's approach of three-dimensional model within the paradigm of Critical Discourse Analysis (CDA) and of the qualitative research, this study aims to identify the ideology enacted in a news article which reports the appointment of Susi Pudjiastuti as the Indonesian minister of maritime affairs and fisheries. It does so by analysing the textual, the discursive, and the social practices of the news discourse. Underpinned by the results of the analysis, this research also investigates the integration of CDA in English classrooms in Indonesia. The results of this study reveal that the patriarchal ideology is enacted in the news through (1) the construction of language use in comparing the qualifications of Susi with Indroyono Soesilo as the coordinating minister for maritime affairs; (2) the use of direct and indirect speech constituted intertextuality; (3) the enquiry of socio-political contexts surrounding the news discourse in relation to women's participations in politics. Based on these findings and Cot's framework, this research also attempts to design a reading task using the news article by constructing consciousness-raising questions, so that students can enhance their critical thinking skills and their ability to reveal hidden meanings in discourse. The implications of the research both in the theoretical importance and in the English language teaching are also discussed with reference to intercultural issues.
\end{abstract}

Keywords: critical discourse analysis, news discourse, ideology, patriarchy

\section{ABSTRAK}

Tujuan Sebagai salah satu sarana di mana agenda tertentu dapat dibentuk dan disebarluaskan, media berita memiliki peranan yang penting dalam mereproduksi hubungan kekuasaan dan ideologi. Dengan menggunakan pendekatan Fairclough's three-dimensional model dalam paradigma Critical Discourse Analysis (CDA) dan penelitian kualitatif, studi ini bertujuan untuk mengidentifikasi ideologi pada artikel berita yang meliput mengenai pelantikan Susi Pudjiastuti sebagai menteri kelautan dan perikanan Indonesia. Berdasarkan hasil analisis data tersebut, penelitian ini juga mengkaji penerapan CDA pada kelas Bahasa Inggris di Indonesia. Hasil penelitian ini menunjukkan bahwa berita tersebut mengandung ideologi patriarki melalui (1) konstruksi penggunaan bahasa untuk membandingkan Susi dengan Indroyono Soesilo sebagai menteri koordinator bidang kemaritiman; (2) penggunaan kalimat langsung dan tidak langsung yang termasuk dalam intertextuality; (3) pengkajian konteks sosial dan politik pada berita tersebut dalam kaitannya dengan partisipasi wanita dalam politik. Berdasakan hasil penilitian dan mengacu pada Cot's framework, penelitian ini juga mendesain reading task menggunakan artikel berita tersebut dengan membuat consciousness-raising questions agar siswa dapat meningkatkan kemampuan berpikir kritis dan kemampuan untuk mengungkap maksud tersembunyi pada discourse. Implikasi penelitian ini dalam literatur dan pengajaran bahasa Inggris juga dibahas dalam kaitannya dengan isu-isu interkultural.

Kata Kunci: critical discourse analysis, berita, ideologi, patriarki

*Author(s) Correspondence:

E-mail: wsantoso@bundamulia.ac.id 


\section{INTRODUCTION}

In Critical Discourse Analysis (CDA), the term 'discourse' is drawn on Foucault (1982) who defines it as a set of ideas or beliefs. In this regard, ' $\mathrm{D}$ ' in CDA corresponds to big ' $\mathrm{D}$ ' which refers to ideas and how they are articulated (Gee, 2011). Fairclough (1992a) states that in CDA, discourse and social structure are interrelated, thus, discourse is perceived as a social practice. On the one hand, discourse is constrained and shaped by social structures such as norms, social class, and power. On the other hand, discourse is socially constitutive. As Fairclough and Wodak (1997) argue, discourse constitutes object of knowledge, social identities, and the relationship between groups of people. In this view, discourse concerns about important issues of unequal power relations such as, gender, ethnic majorities and minorities, and social classes. Additionally, CDA is not seen as a single method, but it is an approach encompassing various perspectives for investigating the relationship between the language use and social contexts (Wodak \& Meyer, 2009a).

One of the causal effects of discourse which have been the main concern for CDA is ideological effects - the effects of texts in establishing and maintaining or changing ideologies (Eagleton, 1991; Larrain, 1979; Thompson, 1984; van Dijk, 1998). The notion of ideology first appeared in the late $18^{\text {th }}$ century and has been used for about two centuries (Thompson, 1990). Thompson (1990) states that ideologies are social forms within which and by means of which hegemonic symbolic forms circulate in the social world. Fairclough (2003) emphasises that ideology is the representations of the world which contribute to constructing, sustaining, and changing social relations of domination. van Djik (1998) adds that ideologies are not just any kind of beliefs, but the fundamental beliefs underlying the social representation shared by a group, featuring values and norms which may be used or abused by social groups to impose or defend for its own interests. He further argues that ideologies should not be seen as an inherently negative concept because ideologies are not only used to legitimate power abuse, but also to reinforce resistance, as is the case for the feminist and the socialist. While the descriptive views of ideology tend to consider the ideology as attitudes, beliefs, and perspective, the critical views of ideology make reference to relations of power and dominations between groups (Fairclough, 2003). In CDA, the latter is espoused because discourse is perceived as social practices that play a crucial role in the reproduction of society, and their knowledge and ideologies.

This study attempts to unpack power relations and ideologies behind discourse, particularly in the news media. As these aspects are not expressed directly, CDA is a useful analytical tool to reveal the ways texts are constructed and to uncover meanings from social, cultural, and political perspectives. In addition, based on the analysis of the news discourse, this study investigates possible ways of how CDA can be incorporated in English classrooms.

\section{THEORETICAL BACKGROUND}

\section{Critical Discourse Analysis}

The term 'CDA' appears to have been used first by Fairclough (1985) who constructs his approach based on the assumption that social analysis has to include a focus on language. van Dijk (2001) defines CDA as a type of discourse analytical approach concerning about the way dominance, inequality, and social power abuse are enacted and reproduced by texts in socio-political contexts. Moreover, Fairclough (1992a) adds that CDA focuses on how power relations shape and transform the discourse practices of a society. Elsewhere, Fairclough (2013) differentiates CDA from other analyses, that is, CDA (1) is an analysis examining the relations between discourse and elements of the social process; (2) goes further than general commentary on discourse as it includes a systematic analysis of texts; (3)

\footnotetext{
*Author(s) Correspondence:

E-mail: wsantoso@bundamulia.ac.id
} 
challenges social wrongs and possible ways of mitigating them. However, it is important to note that these aspects of CDA are not rules, but as a tool to draw essential distinctions.

In general, CDA particularly aims for social change in the society. As Tenorio (2011) states, CDA is a discipline designed to question the status quo by resisting enactments of power in discourses. Furthermore, Fairclough and Wodak (1997) note that CDA concerns about deciphering texts and revealing the opaque relationship between discourse and social practice. The analysis of texts can be accomplished through open interpretations by achieving distance from the data and putting them in contexts. Interestingly, Fairclough and Wodak (1997) also argue that CDA is "a form of intervention in social practice and social relationships" (p. 258, my italics). In this respect, intervention may mean that CDA intervenes on the side of dominated group and oppressed group and reveals the interest that lies in a certain discourse. It should make proposals for change and suggest corrections to particular discourses. This is in line with the term 'critical' in CDA which is described by Fairclough (1992a) as showing connection and causes which are hidden by providing resources through change. Also, Wodak and Meyer (2009b) state that CDA attempts to demonstrate how social phenomena are interconnected to generate knowledge that allows the society to emancipate themselves from domination, and to eliminate delusion by revealing power and ideologies behind discourse. Synthesizing the definitions of CDA, in this study, CDA seeks to expose the manipulative nature of discursive practices and uncover meanings in discourse in order to show power, ideologies, interests, and beliefs attached to it.

Contrary to traditional linguistics, the study of discourse is not restricted to grammars or abstract sentences, but focuses on authentic language use of real language users in real social situations of interaction and communication (van Dijk, 2009). In other words, the meaning of discourse does not come into being until it is actively employed in a context of use (Mogashoa, 2014; Wodak, 2002). Wodak (2002) also argues that for CDA, language is not powerful on its own because it gains power by the use powerful people make of it. Hence, CDA often chooses the views of those who suffer and are oppressed, and critically analyses the language use of those in power, who are responsible for the existence of inequalities and who also have the power to improve conditions.

\section{Proponents of CDA}

There are several key names who have contributed significantly to the development of CDA. van Dijk (1995) advocates the sociocognitive model in CDA, referring to an approach focusing on the interaction between cognition, discourse, and society. What differentiates van Dijk's approach to other approaches can be the aspect of cognitive analysis. van Dijk (1995, p.18) views sociocognition as "the system of mental representations and processes of group members." In other words, a social group tends to share similar sociocultural knowledge towards certain beliefs and attitudes. Therefore, the knowledge in the memory is assumed to indirectly control the society's perceptions and understanding of discursive practice.

While van Dijk is known for his sociocognitive model, Wodak is particularly recognized for his historical approach in discourse (Martin \& Wodak, 2003). Similar to Fairclough's notion of intertextuality, Wodak and Ludwig (1999) perceives discourse as historical, meaning that it is interrelated to other communicative events. Like Fairclough (1995) who supports open interpretation, Wodak (2001a) also emphasizes that CDA should attempt to make choices and justify the reason why particular interpretations seem to be more valid than others. In other words,

*Author(s) Correspondence:

E-mail: wsantoso@bundamulia.ac.id 
interpretations cannot be true, but they can be more or less plausible.

Another major proponent of CDA is Fairclough (1989) who believes language is an irreducible part of social life. Even though Fairclough (1992a) acknowledges that several scholars such as, Foucault and Althusser have proposed the importance of ideology in their approaches and the social aspect of language, he still questions whether such theory raises the social importance of language. Therefore, he develops a multidimensional approach called the social theory of discourse which can be used to assess the relationship between discursive, social change, and properties of texts (cited in Fairclough, 1992a). The implication of this approach in language education is reflected in Critical Language Awareness (CLA) which has the purpose to raise students' awareness of social relations and issues by focusing on language (Fairclough, 1992b).

\section{Critiques of CDA}

Even though CDA can alter one's way of thinking about language as carrying power and ideology (McGregor, 2010), there has been a range of critical arguments towards CDA. The term 'discourse' is used in numerous ways within the field of discourse analysis (Wodak, 2011; van Djik, 2009). Widdowson (1995a) also claims that the term 'discourse' in CDA is vague because "discourse is something everybody is talking about but without knowing with any certainty just what it is: in vogue and vague" (p. 158). $\mathrm{He}$ also points out that there are no clear distinctions between texts and discourse because different researchers can use the term 'discourse' in different ways, for example, while there is a distinction between 'text' and 'discourse' in the German and European contexts, in English-speaking contexts, 'discourse' can mean both written and spoken texts.
Another critique of CDA is associated with the use of Systemic Functional Linguistics (SFL) which considers language as a network of systems or choices for expressing meanings (Flowerdew, 2013). Jones (2007) says that the utilization of SFL for analyzing linguistic features contradicts with Fairclough's claim stating that CDA is based upon semiotics as part of social process. In addition, although Widdowson (2004) does not oppose CDA's cause, he is aware of its shortcomings. He criticizes the focus of the language analysis that is deemed bias to draw conclusions regarding ideologies because researchers tend to choose the language features which will provide results that have ideological meanings (ibid). Therefore, researchers should adopt critical attitudes towards its practices and be explicit in methodological procedures.

\section{Patriarchy in News Discourse}

The relationship between news media and their impacts on socio-political contexts has been widely discussed in the literature. News media seem to be neutral because they offer space for public discourse and reflect situations independently. Nevertheless, they often have hidden socio-political agenda and relations of power and ideologies that they want to address with the purpose of manipulating readers to accept their view of particular events (Fairclough, 1992a; Kim, 2014; Montiel, 2015; van Dijk, 2009; Wodak \& Busch, 2004). Fowler (2013, p. 1) also insists that "language is... a highly constructive mediator" and the linguistic choices made by the writers are often ideologically motivated. In other words, what is presented in the news is selected according to a set of criteria and values that are carefully constructed to support a certain interest. Thus, as Fowler (1991) argues in his seminal work on news discourse, the content of newspapers is not merely facts about the world, but in very

\footnotetext{
*Author(s) Correspondence:

E-mail: wsantoso@bundamulia.ac.id
} 
general sense "ideas", thus, it is inevitably not a value-free reflection of reality (p. 1).

Not only the proponents of CDA, some feminist scholars also argue that media are not gendered neutral and are often driven by the patriarchal ideology (Montiel, 2015), defined as a system of male dominance over women in society (Christ, 2016; Montiel, 2015; Sultana, 2011). Patriarchy also tends to differentiate between the role and the significance of men and women. The structures of such ideology are divided into positive descriptions of men (e.g. independent and strong) and negative descriptions of women (e.g. dependent and weak), hence defining opposed identities, and different norms and values that define the power of men in society (Murtiningsih \& Elmada, 2017; van Dijk, 2009). Montiel (2015) further states that while men are usually portrayed as competent individuals the public sphere, women are often associated with the domestic sphere and is portrayed as being less able than men to perform in any field of public sphere, especially politics.

In Indonesian contexts, the belief that politics is more suitable for men and is not proper for women still exists (Nilan \& Demartoto, 2012; Salviana \& Soedarwo, 2014). As Salviana and Soedarwo (2014) state, the perception that politics is full of tricks may trigger the exclusion of women in political activities. Although the percentage of women office holders has generally increased in Indonesia since the mid $20^{\text {th }}$ century (Maula, 2010), women are still perceived as subordinate to male politicians due to their social roles in family contexts (Salviana \& Soedarwo, 2014). As a result, the political actions of female politicians may be influenced by the patriarchal ideology in the sense that they tend to be under the power of male politicians.

As the discussion of gender or portrayal of women cannot be separated from accounts of ideology and power, CDA can uncover how discourse structures established through various linguistic patterns and structures (micro-level notions), work to convey the social cognitions (macro-level notions), which contribute to the development of the inequality and injustice of power in society.

\section{Applications of CDA to Teaching in Indonesian contexts}

Not only does CDA alter one's way of thinking about language as carrying power and ideology (McGregor, 2010), but also it contributes specifically to English Language Teaching (ELT). This critical approach is in line with a view of education which emphasizes the enhancement of students' capacities to evaluate and judge the world carefully and, if necessary, to change it (Cots, 2006). Some researchers have suggested the incorporation of CDA to teach higher order thinking skills to students (e.g. Faramarzi, Elekaei, \& Tabrizi, 2016; Karimi \& Veisi, 2016; Wang \& Zheng, 2016). In a study in English as a Foreign Language (EFL) contexts, Hashemi and Ghanizadeh (2012) found that the integration of CDA into English classrooms allowed students to critically recognize and interpret unstated assumptions in discourse. Similarly, Rahimi and Sharififar's (2015) study also revealed that CDA helped students nurture critical thinking and enhance their motivation to read. Moreover, CDA has also been utilized in CLA which can develop students' self-awareness of social circumstances and power relations so they can critically reflect on how language is used in certain discourse (Fairclough, 1992c). Thus, the advantages of using CDA in ELT seems to be evident not only in developing students' critical thinking, but also in raising their awareness of roles of discourse.

Additionally, CDA contributes to developing students' cultural awareness, that is, the capacity to problematize constructions of cultural groups and how these control

*Author(s) Correspondence:

E-mail: wsantoso@bundamulia.ac.id 
positions (Kocatepe, 2005). He further maintains that CDA can offer a framework for explaining the relationship between language and cultures, thus, students can reflect on how cultures are portrayed in discourse through language. Similarly, Hyde (1994) argues that CDA helps students to respond to the pressures of external cultures and to criticize the representations of cultures in discourse. Therefore, they may have the ability to resist being positioned to accept certain worldviews so it can liberate them from imposed norms and cultures in discourse.

Nevertheless, CDA also presents some challenges to be applied in the classroom such as, the appropriateness of the topics of the materials. Zaid (1999) states that some topics in teaching materials may contain culturally inappropriate issues by exposing certain social behavior that is unacceptable according to students' cultures. Topics such as, religions may be appropriate in the contexts where such issues are not considered sensitive. However, in contexts such as Indonesia, this topic can pose a problem. As Wahjusaputri (2015) argues, although Indonesia is a pluralistic country where various background of tribes and religions exist, it is still deemed inappropriate to discuss topics related to religions in the classroom due to the current situation in which discrimination to some minor religious groups are still happening in Indonesia. Discussing such topic in the classroom may create tense and uncomfortable atmosphere for some students who perceive themselves to be in the inferior position. Hence, it is important for teachers to consider sociocultural issues in their teaching contexts in using and adapting materials for CDA so they can give appropriate topics for their students.

In addition, there has been a concern about the types of materials used in the classroom. Since CDA often uses authentic materials which are defined by some scholars (e.g. Harmer, 2007) as materials designed by native speakers, others warn possible negative impacts of using authentic materials from English-speaking countries. Such materials may not only present difficulties for learners with low-level of proficiency (Kilickaya, 2004), but also trigger issues related to cultural content (Jayanti \& Norahmi, 2014). According to Jayanti and Norahmi (2014), there has been an ongoing debate in Indonesia regarding which cultures and which English varieties should be included in teaching materials. Kirkpatrick (2007) maintains that it is the culture of the Indonesian people and Asian varieties of English which are important to be incorporated into the materials because English has become a lingua franca (ELF) in Asian contexts.

Regarding the cultural content, teachers are advised to choose local authentic texts because in fact, the degree of authenticity can also be seen from, as Breen (1985) argues, students' own interpretations of texts. If students are familiar with the sociocultural issue being discussed and it is related to their lives, it could be argued that the text is authentic because it may engage their interest, leading to authentic interpretations towards the text. However, in relation to varieties of English, choosing Asian varieties might be challenging for teachers because teaching materials for CDA such as, advertisements, posters, and political speech using such varieties may not be widely available due to the native speaker norms that still dominate ELT in Indonesia (Jayanti \& Norahmi, 2014).

\section{Previous Studies in Indonesian Contexts}

Although numerous studies of CDA covering the representation of patriarchy in news discourse have been conducted, there is still limited research on this subject in Indonesian contexts. For instance, Murtiningsih and Elmada (2017) investigated Tribunnews.com using the descriptive qualitative content analysis approach combined with CDA and found that the news

\footnotetext{
*Author(s) Correspondence:

E-mail: wsantoso@bundamulia.ac.id
} 
had not been fully able to raise women's issues. This study also revealed that women were still portrayed negatively within the patriarchal culture, discrimination, and consumeristic lifestyle. Moreover, the news did not highlight intellectual and leadership values of woman as actors. Instead, it promoted gender bias by exploiting female's physical appearance.

Susilo (2017) examined news texts about violence on women from 2014 to 2015 on Tribunnews.com and its regional networks using the CDA framework proposed by Van Dijk. Like Murtiningsih's and Elmada's (2017) research, the result of this study showed that the patriarchal ideology seemed to be present in the news discourse. This research also revealed that the news positioned women as the submissive victims and the male's sexual object, strengthening masculine domination over feminine beings.

A more recent study conducted by Risdaneva (2018) compared the portrayal of women in the Jakarta Post and the Guardian using naming analysis, which is a part of CDA. Unlike some previous studies (e.g. Murtiningsih \& Elmada, 2017; Susilo, 2017), this research focused on how both newspapers used the choices of the naming categories in reporting crimes of sexual violence against women. This research result demonstrated that while the Jakarta Post attempted to protect the identity of the victims by using pseudonyms, the guardian seemed to classify the victims in terms of age and gender and refer to their surnames. This may imply that the Jakarta Post treated the victims as important participants who needed protection and support.

Another qualitative research done by Amri (2018) compared Fajar and Tribun Timur Daily using Fairclough's framework. The finding of the research, which concerned about raping and prostitution is similar to some prior studies (e.g. Murtiningsih \& Elmada, 2017; Risdaneva, 2018; Susilo, 2017) showed that both newspapers were still male- dominated discourse in the news content. In addition, this research also looked at the newsmaking process and showed that there was a contradiction between the news content and the news-making process. Although the textual analysis demonstrated gender issues, the interviews with the news makers revealed that female journalists were given opportunities to express their voices to avoid gender discrimination.

\section{Rationale for the Research}

The studies in Indonesian contexts have mainly focused on the portrayal of women as an object of victimization associated with sexual representations. The lack of research on the analysis of news discourse that raises issues of women's participations in politics, especially in Indonesia has become the rationale for this study. As Salviana and Soedarwo (2014) state, the socio-political situations may obstruct women to get involved in politics because the process of candidate selection in political parties tend to be gender bias where male characteristics are emphasized. In Indonesia, women are also viewed as isolated and lacking adequate political power (Ida, 2001). In this case, news media are considered a powerful tool to reproduce unequal power relations in society. As Li (2009) asserts, media language as discursively constrained and situated suggests the importance of studying how media texts transform different discourses because this way may provide insights into the processes of ideological and reality construction in the media. Thus, revealing underlying meanings and ideologies behind news media is needed because as Fairclough (1995) notes, such analysis is an essential element within research on processes of social and cultural change.

Regarding ELT in Indonesia, the language policy has incorporated critical and interactive learning emphasizing the interaction between students and societal contexts into the curriculum (Ministry of

*Author(s) Correspondence:

E-mail:wsantoso@bundamulia.ac.id 
Education and Culture, 2013 as cited in Larson, 2014). It means that the government supports teachers to equip students with critical thinking abilities, especially in the secondary and higher education. Moreover, CDA is compatible with Critical Pedagogy (CP) (see Flowerdew, 2013) which is considered necessary in Indonesian contexts (see Larson, 2014; Mambu, 2011). Similar to CDA, CP also requires students to utilise "problem-posing techniques" to evaluate knowledge received from texts and to relate them to social contexts (Jeyaraj \& Harland, 2014, p. 344). Therefore, CDA may be applicable in Indonesia as it does not clash with the educational policy and is in line with $\mathrm{CP}$ which is relevant to Indonesian contexts. This study suggests the implementation of CDA underpinned by the results of the analysis in order to see possible ways of developing students' higher order thinking skills as advised by the government.

Prior research on news regarding the patriarchal ideology in Indonesia has looked at big data (e.g. Amri, 2018; Murtiningsih \& Elmada, 2017; Risdaneva, 2018; Susilo, 2017). As a consequence, these studies might not probe the complexity of the issues and facilitate comprehensive understanding of social inequality within the socio-political context. As small-scale research seems absent in this context, thus, study presents an in-depth analysis of a news text that exposes gender issues related to women's portrayal in politics. This research aims at investigating the ideology in a news article about the appointment of Susi Pudjiastuti as the minister of maritime affairs and fisheries, and proposing the incorporation of CDA in English classrooms in Indonesia.

\section{METHODOLOGY}

The purposes of this research enquires into discourses of power and ideologies in news reporting on the appointment of a female's Maritime Affairs Minister in Indonesia. For these aims, the CDA framework proposed by Fairclough (1992a) for the study of the relations between discourse and social and cultural phenomena was adopted because as Janks (1997, p. 329) states, it provides the interrelation between the dimension of discourse and the "interesting patterns and disjunctions that need to be described, interpreted, and explained." Thus, this study was qualitative research which aims at understanding and interpreting the meaning of the data (Creswell, 2014; Robson, 2013).

Fairclough's (1992a) model called a three-dimensional framework was used in the data analysis and was applied to relate micro levels of language use to wider aspects of social practice. In this framework, discourse as text focuses on language analysis of texts contributing to conveying a message (Fairclough, 1992a; Richardson, 2007). In this sense, the word 'text' refers to both written and spoken texts. Meanwhile, the discursive practice refers to how a text is produced, distributed, and consumed in society (Fairclough, 1992a; Richardson, 2007). Fairclough (1992a, 2013) also states that this dimension covers intertextuality where texts are shaped by subsequent texts. Ultimately, discourse as social practice addresses issues in social analysis related to power and ideology (Fairclough, 1992a).

However, a possible limitation of this model is that as Fairclough (1992a) says, there might be an overlap between analysis of texts and of discursive practice because discursive practice also involves formal features of texts. Despite this limitation, following Widdowson (1995b), Fairclough's framework is effective as it shows the ways texts are constructed, reveals how they can become relevant to an understanding of social contexts, and uncovers meanings from socio-political perspectives.

To propose the integration of CDA in Indonesia, Cots' framework (2006) which follows Fairclough's (1992a) model of CDA

\footnotetext{
*Author(s) Correspondence:

E-mail: wsantoso@bundamulia.ac.id
} 
was adopted. These frameworks include (1) social practice where students reflect on how the textual representation is constructed by ideology and how it contributes to altering the reader's ideological position, (2) discourse practice where students focus on the communicative situation such as the intended reader, (3) textual practice where the linguistic features of the text are discussed. This framework was chosen as the basis for forming consciousness-raising questions to students, so that they could develop their ability to decipher hidden assumptions in discourse. The activity proposed is a reading task using the text previously analyzed. The students were taking the Critical Reading class in the English education program in an Indonesian university (see the detailed activity in Appendix 1). Moreover, reading strategies such as, skimming and scanning as suggested by Grabe (2008) were also integrated in this task. The students might use such strategies depending on the questions asked in the task.

The news text was entitled "Aviation Tycoon Susi a Surprising Pick as Joko's Maritime Affairs Minister" ("Jakarta Globe", 2014) (see Appendix 2) taken from Jakarta Globe, a daily online English language newspaper in Indonesia. The appointment of Susi Pudjiastuti as the maritime affairs and fisheries minister has provoked both pros and cons. While some people think that she might be able to make a breakthrough in the maritime sector, others assume that she does not have adequate experiences and knowledge to get involved in politics. The rationale for choosing this news article is that the text contains issues related power and gender, which are relevant for interpretation and explanation using CDA (Wodak, 2001b). When incorporated into the teaching task, the topic of this text is also suitable for the students considering the sociocultural issues in Indonesia. Moreover, these subjects are presented in mass media which are often not neutral (Fairclough, 1989), thus, it is expected that the analysis can reveal the underlying assumption in the text.

\section{RESULTS AND DISCUSSION}

\section{Ideology Underlying the Text}

Discourse as Text

This part of analysis focuses on analyzing the language choices made by the author of the text (Fairclough, 1992a; Richardson, 2007). Looking at the word choice in the headline, i.e. 'Aviation Tycoon Susi a Surprising Pick as Joko's Maritime Affairs Minister', the writer seems to use the vocabulary to make a contrast between the qualification of Susi and her current career in the government. The noun phrase 'aviation tycoon' describes Susi as a wealthy person in the aviation business. The word 'tycoon' may convey a negative meaning to Susi's public image because a rich person who can join the government is usually selected due to his/her close relationship with the government. The following noun phrase, 'a surprising pick', may show that Susi's new position in the government is unexpected because of her previous work experience. The writer also adds Susi's position 'as Joko's maritime affairs minister'. This phrase shows possession emphasizing that it is Jokowi who chose Susi to be the maritime affairs minister in his cabinet. In this headline, Susi seems to be portrayed negatively as a business woman who has no relevant work experience is now working as the maritime minister because Jokowi, the president, chose her to work in that position. This portrayal may also indicate that there is a certain interest between Jokowi and Susi, which may make this decision subjective.

This finding may demonstrate that the words used in the headline can carry certain meanings that the writer attempts to express. Fairclough (1992a) states that a news headline is design to construct and signify social relationships, belief, and knowledge. The

*Author(s) Correspondence:

E-mail: wsantoso@bundamulia.ac.id 
portrayal of Susi in the headline as a rich aviation businesswoman who is chosen to be the maritime affairs minister might indicate the writer's intention to attract readers' attention not only to read the news, but also to recall it. As Fairclough (1992a) argues, headlines are usually short and catchy to make readers aware of the news. He further states that journalists tend to exploit the use of headlines to express their perspectives of the news they report (ibid). From the headline, it can be inferred that the writer might view Susi as an unqualified candidate due to her prior professional career. In addition, Fairclough (1992a) argues that news media have certain agenda that they want to address such as, competing with other newspapers to persuade the readers to read the newspaper, so that they can raise their profit in their sales. An appealing headline in this news may raise the readers' curiosity to know what makes Susi a 'surprising pick' as the minister, thus, such headline can encourage them to access the news.

In the first paragraph, the sentence is loaded in terms of how the vocabulary and grammar are used to create public image.

“While President Joko Widodo's choice of Indroyono Soesilo as coordinating minister for maritime affairs was welcomed by the business community, the appointment of Susi Pudjiastuti as the minister of maritime affairs and fisheries was met with surprise in view of her apparent lack of any strong maritime background." (par. 1)

This section is structured using two clauses which have the connector 'while' to show a comparison between Indroyono Soesilo, a new coordinating minister, and Susi. She is again put in a subordinate position where she is portrayed as incapable of being a minister. For example, these clauses use passive forms in which the first clause shows that the employment of Indroyono "was welcomed by the business community" (par. 1). The passive verb 'was welcomed' gives a positive impression to the reader that Indroyono is a qualified candidate as 'the business community' accepts him. Also, the writer tends to overgeneralize the words 'business community', implying that 'all' business communities welcomed him. In the second clause, the passive verb is followed by a noun phrase giving the reader a negative perception towards Susi. Moreover, the writer attempts to play some strong words such as, "her apparent lack of any strong maritime background" (par. 1) whose usage appears to create a bad image for Susi. It is also interesting to note that the word 'surprise/surprising' appears three times in the news article (see headline, par.1, par.8), emphasizing that Susi is an unforeseen and, in some way, unwanted minister.

This result may demonstrate that the use of comparison between both political figures in the sentence is used to emphasize a contrast in terms of the acceptance of the public regarding their appointment as the ministers. The positioning of the comparison at the beginning of the paragraph possibly implies the importance of the message that the writer wants to convey. As Fairclough (2015) notes, text analysis should pay attention to the analysis of the text structure since ordering in news that is based on importance may point out the main content that the writer is trying to communicate to the readers. Thus, in the news article, the headline and the first paragraph contain information that is considered essential by the writer, that is, Susi is deemed incapable of being a maritime minister compared to Indroyono.

Interestingly, throughout the article, the text is still structured by mainly comparing Indroyono and Susi although sometimes the comparisons are implied.

\footnotetext{
*Author(s) Correspondence:

E-mail: wsantoso@bundamulia.ac.id
} 
"Susi is a senior high school dropout who started her business as a brokerage buying fish from fishermen in Pangandaran, West Java, in 1983." (par.4)

"Indroyono, who earned his Ph.D. in geologic remote sensing at the University of Iowa in the United States in 1987, has a long list of experience in the government and international organizations." (par. 10)

"Indroyono was the first Indonesian to occupy a high-level position in the Food and Agricultural Organization. He was the director of the fisheries and aquaculture resources use and conservation division at the FAO headquarters in Rome." (par. 11)

"He also has experience in high-level positions in the office of the coordinating minister for people's welfare and the former ministry of sea exploration and fisheries." (par. 12)

More detailed information of educational background and work experience is also present (see par. 3-6, par. 10-12). Fowler (1991) states that the news does not simply contain facts, but also ideas, meaning that the writer can incorporate his or her subjective views towards the subject being reported. Although the writer presents some facts in this news by making a comparison between Susi, who is a senior high school dropout and running an aviation business, and Indroyono, who is a $\mathrm{PhD}$ graduate and having experiences in working in fisheries sectors, the writer may utilise these facts to support his/her main argument, that is, Susi is 'a surprising pick' as the minister.

\section{Discourse as discursive practice}

This stage emphasises the processes of text production, distribution and consumption (Fairclough, 1992a). Regarding the text production, it is not clear who the author is as the article is anonymous. This text is taken from the news section rather than the opinion's section of the online newspaper, indicating that it is the writer working in Jakarta Globe who has written this news. In relation to the distribution, this text seems to be distributed across different contexts, and it covers a wide range of audience as it is published online and written in English. Furthermore, considering the consumption of the text, although this text is widely distributed, it could be argued that the main target audience of this text could be the Indonesian people who support Jokowi's leadership because this text seems to raise the issue of distrust, making them doubt not only the capability of Susi as the maritime minister, but also Jokowi as the president who is responsible for choosing his ministers (see the headline, par. 4). Thus, this text also carries emotive dimensions which, as Bax (2011) argues, can evoke people's feelings and change their attitudes. The proponents of Jokowi who first support the government may alter their views and perceive that the current government cannot run well as the minister is not the expert in the maritime industry. Moreover, the writer also states that the maritime sector is "the centerpiece of his (Jokowi's) policy platform" (par. 13). Although he/she cites Jokowi's statement, he/she may incorporate his/her opinion by choosing the word 'centerpiece' to emphasize the importance of the capability of a minister in dealing with the maritime industry because it is the major sector in Jokowi's government. As a result, such descriptions may negatively affect or even change the stance of Jokowi's proponents towards his leadership as they may question the capacity of the minister.

Regarding the intertextuality, Fairclough (1992a) states that an example of intertextuality is direct and indirect speech. In the text, there are only one quotation taken from Jokowi, who gives a positive description of Susi.

\footnotetext{
*Author(s) Correspondence:

E-mail: wsantoso@bundamulia.ac.id
} 
"She was an entrepreneur who started her business from scratch, successful in her aviation business that is integrated with the maritime industry," Joko said when introducing Susi outside the State Palace on Sunday. (par. 3)

Meanwhile, the other quotation is cited from Jeffrosenberg Tan, the portfolio manager at Sinar Mas Asset Management, who doubts over Susi, but is confident with the appointment of Indroyono as the coordinating minister for maritime affairs.

"Is that the right person in the right place? It is just quite surprising, but there is no need for any negative comments for now. She may perform, let's give her some time," he said. (par. 8)

The writer only uses one indirect speech cited from Jeffrosenberg.

"Jeffrosenberg expressed confidence over the appointment of Indroyono, given his strong background in the maritime sector." (par. 9)

It could be argued, however, Jeffrosenberg may not be a suitable person to be interviewed regarding this topic as he is a businessman whose expertise is not in the maritime industry (see par. 7). Thus, there might be a possibility that the writer has a certain interest in choosing Jeffrosenberg. One of the reasons could be he supports Indroyono, but he is against Susi. Therefore, his argument may be used to support the writer's intention which aims to show the incapability of Susi as the new minister.

Moreover, the text is dominated by the voice of the writer rather than those of the reported as only a few direct speeches are used. In some of the paragraphs, the writer uses several phrases that have strong words in the indirect speeches. For instance:

“... was met with surprise in view of her apparent lack of any strong maritime background". (par. 1)

"her business background does not impress Jeffrosenberg Tan,..." (par 7)

"Jeffrosenberg expressed confidence over the appointment of Indroyono... ” (par. 9)

"... has a long list of experience in the government and international organizations." (par. 10)

"He also has experience in high-level positions in the office of the coordinating minister for people's welfare and the former ministry of sea exploration and fisheries." (par. 12)

As Fairclough (1992a) states, tenses and deictics are shifted to integrate the writer's perspective. In other words, by using a few direct speeches, the writer could add sentences which can represent his/her views towards the subject. As a result, the use of such words makes this news less objective.

\section{Discourse as social practice}

This stage focuses on how ideology and power are reflected in discourse (Fairclough, 1992a, 2015). Bax (2011) asserts that analyzing the social practice needs to include questioning the socio-political contexts and ideology underpinning the text, and revealing hidden assumptions in it. The result of this study shows that this text may have socio-political aims which attempt to provoke criticisms from the society towards Susi and Jokowi due to her employment, which is portrayed as an inappropriate choice through the vocabulary and grammar used as mentioned in the previous section.

The text arguably carries the patriarchal ideology, defined as the manifestation of male dominance over women in society (Christ, 2016; Montiel, 2015;

*Author(s) Correspondence:

E-mail: wsantoso@bundamulia.ac.id 
Sultana, 2011). The comparisons between Susi and Indroyono are made in terms of their previous work experiences and their academic background. For example:

"While President Joko Widodo's choice of Indroyono Soesilo as coordinating minister for maritime affairs was welcomed by the business community, the appointment of Susi Pudjiastuti as the minister of maritime affairs and fisheries was met with surprise in view of her apparent lack of any strong maritime background." (par.1)

"Susi is a senior high school dropout who started her business as a brokerage buying fish from fishermen in Pangandaran, West Java, in 1983." (par. 4)

"Indroyono, who earned his Ph.D. in geologic remote sensing at the University of Iowa in the United States in 1987, has a long list of experience in the government and international organizations." (par. 10)

In line with some of the previous research (Murtiningsih \& Elmada, 2017; Susilo, 2017; Risdaneva, 2018), the finding of this study demonstrates that the issue of gender and inequality appears to be evident in the news article, and the writer presents it by comparing the qualifications of Susi and Indroyono. Some scholars (e.g. Fairclough, 1992a; Kim, 2014; Montiel, 2015; Wodak \& Busch, 2004; van Djik, 2009) express their concerns about the role of media which have hidden socio-political agenda to reproduce unequal power relations and ideologies. These phenomena are assumed to organise and control the development of sociocultural knowledge through the minds of the society (van Djik, 1995). In other words, the manipulative nature of discursive practices may influence the readers to accept the writer's views. Therefore, revealing the power and the ideology behind this news article may raise awareness of unstated assumptions in the text, thus, as Wodak and Meyer (2009b) argue, CDA may promote the ability to emancipate the society from imposed norms and certain worldviews.

The result of this study arguably offers new insights in the literature as this research addresses women's roles in politics, an issue which still receives little attention in the field of CDA in Indonesian contexts. Although Susi is portrayed as a successful businesswoman in the news, her lack of experience in the maritime sector and education is more emphasized. Also, the writer seems to use Susi's successful business to demonstrate that her previous job is not related to the maritime industry. This portrayal may label women as incapable of being a politician because they do not have any qualified skills to become politicians. This corresponds to Ida's (2012) argument stating that Indonesian women are usually perceived as lacking political authority. This assumption may lead to gender bias in which men are deemed more suitable to involve in politics compared to women (Nilan \& Demartoto, 2012; Salviana \& Soedarwo, 2014).

Additionally, there might be an intriguing enquiry related to the political figures being reported in the news article: why does the writer have to compare Indroyono with Susi? In fact, there are some other female ministers who are also appointed by Jokowi in his cabinet such as, Sri Mulyani Indrawati, Retno Marsudi, and Rini Mariani Soemarno. Unlike Susi, these politicians have relevant qualifications in terms of educational backgrounds and work experiences. Yet, one could argue that the writer might select Susi to reproduce unequal power relations in politics and emphasise the exclusion of women in this sector. This finding is in line with the result of Murtiningsih's and Elmada's (2017) study showing that the news does not report leadership skills and intellectual characters of

*Author(s) Correspondence:

E-mail: wsantoso@bundamulia.ac.id 
women. Perhaps, this news would have given a more positive description of Susi if it used her previous work experience in the aviation business to show the connection with the maritime sector.

Interestingly, gender inequality is also reflected in how the writer describes Jeffrosenberg's perception towards Susi.

"However, her business background does not impress Jeffrosenberg Tan..." (par. 7)

It could be concluded that there might be an issue of male dominance in which women should 'impress' men through what they do even in the workplace. This result of the study is similar to Salviana's and Soedarwo's (2014) argument stating that that women are still seen as subordinate to men and that they are under the male power.

Another evidence for the patriarchal ideology is demonstrated in Jeffrosenberg's quotation.

"Is that the right person in the right place? It is just quite surprising, but there is no need for any negative comments for now. She may perform, let's give her some time," he said. (par. 8)

Since these comments contain a strong doubt towards Susi's capabilities by using the interrogative sentence, the readers may also be persuaded to question the appointment of Susi and her capabilities. Moreover, although Jeffrosenberg states that he does not give any negative comments, the use of 'may' that shows uncertainty and the phrase 'let's give her some time' still imply scepticism towards Susi. Again, there might be an intention to show that women are not able to work as part of the government which is usually dominated by men (Haryanti \& Suwana, 2014). It can be seen that the portrayal of Susi in this text causes her to be in a subordinate position to Indroyono. Hence, the issues of power, gender, and inequality hidden in the text are in fact present.

\section{Incorporation of CDA into English classrooms}

In integrating CDA into English classrooms, Cots' framework (2006) following Fairclough's (1992a) model of CDA are adopted. These frameworks include social practice, discourse practice, and textual practice (see the methodology section).

In the first phase (social practice), the students are required to discuss their opinions about Susi as the new maritime minister before reading the text. The rationale for this prereading activity is to activate students' schematic knowledge to (re)construct "a meaningful mental model of what the text is about" (Neuman, Kaefer, \& Pinkham, 2014, p. 148). After the discussion and the individual reading, they need to analyze and compare how Susi and Indroyono are portrayed in the news article, so that they can draw conclusions based on what the writer says towards Susi and Indroyono. This analysis is to help them discover, as van Dijk (2001) asserts, the way gender and inequality are enacted and reproduced in texts. Afterwards, students may reflect upon their own perspectives of Susi and Indroyono because it is beneficial for them to know, as Cots (2006) suggests, whether there are changes in their perspectives after reading the text, so that they can be aware that what is presented in texts may influence how they perceive a particular issue.

In the second phase (discourse practice), the main purpose is to ask the students to think about the intended readers and the main point that the writer wants to convey to the readers through the text. Thus, these questions may raise the students' awareness that news media often have agenda and that they need to read between the lines to reveal the ideological assumptions in the text

*Author(s) Correspondence:

E-mail: wsantoso@bundamulia.ac.id 
(Fairclough, 1992a; Kim, 2014; Montiel, 2015; van Dijk, 2009; Wodak \& Busch, 2004).

In the last phase (textual practice), the students are asked to underline nouns, adjectives, and verbs used by the writer to describe Susi and Indroyono related to their educational background and work experiences. Additionally, they are also required to think whether the words used either positively or negatively influence the portrayal of Susi and Indroyono. As McGregor (2010) argues, the word choice is often subjective as they carry power and the interests of the speaker. Therefore, by focusing on the linguistic features, the students may be aware of the language use in discourse as it may affect their perceptions of the text.

\section{CONCLUSION}

CDA is a beneficial tool to unpack hidden power relations and ideologies behind discourse. The use of Fairclough's (1992a) framework in this study shows that the patriarchal ideology seems to underpin the news article entitled "Aviation Tycoon Susi a Surprising Pick as Joko's Maritime Affairs Minister" in the Jakarta Globe. This ideology can be seen from the analyses of language use, discursive practice, and social practice that show the negative portrayal of Susi by comparing her qualifications with Indroyono. Such descriptions may affect the readers to think that women are not capable of being a politician, resulting in unequal power relations and discrimination against women. Moreover, when applied in English classroom in Indonesian contexts, CDA can be incorporated with reading tasks using Cots' (2006) framework to help students develop their awareness of unstated ideologies and meanings in discourse.

Despite the small-scale nature of this study, some research implications can be proposed. This research arguably offers a new insight to the literature. Regarding Indonesian contexts where research on this topic remains limited, this study has introduced a different focus in discussing CDA in news media. While numerous studies in Indonesia have investigated the portrayal of women in news by looking at their physical and sexual representations, this research has deepened the literature of the CDA which investigates the patriarchal ideology in politics. The research results showing that such ideology is enacted in the news article may inform news media that they have a critical role in improving or discouraging gender equality. Thus, the language use in the news should be carefully constructed in such a way, so that it promotes emancipation from domination and gender issues.

In relation to ELT in Indonesia, CDA can be utilized to analyze and reveal the underlying power and ideology in discourse and is beneficial for ELT in enhancing students' critical thinking. Some practical applications can be proposed, for example, incorporating $\mathrm{CDA}$ in the reading class to raise students' awareness of underlying assumptions in discourse. Nevertheless, some intercultural issues in implementing CDA such as, the cultural content needs to be considered because as O'Keeffe, McCarthy, \& Carter (2007) argue, language teaching is a complex activity taking place in different contexts and involving teachers and students with different cultural expectations. Moreover, regarding the choice of English varieties, it is unrealistic to expect students to only adopt and use Englishspeaking countries' norms considering the status of ELF in Asian contexts including Indonesia (Jenkins, 2012). Even though this ELF paradigm begins to be promoted, it still presents a new challenge for teachers especially in terms of the availability of ELF materials in Indonesia.

Future research in the field of CDA may examine a written or spoken discourse using English varieties other than what is called the standard English such as, American

\footnotetext{
*Author(s) Correspondence:

E-mail: wsantoso@bundamulia.ac.id
} 
and British English. The results of this analysis can also be utilized to develop learning tasks. In addition, possible issues in using ELF materials and integrating CDA in English classrooms can also be discussed. Ultimately, further research may cover other topics related to patriarchy such as, job opportunities for women and access to education for women.

\section{REFERENCES}

Amri, M. (2018). Gender domination in local newspapers. Jurnal Ilmu Komunikasi, l(1), 1926.

Aviation Tycoon Susi a Surprising Pick as Joko's Maritime Affairs Minister. (2014, October 26). Jakarta Globe. Retrieved

from http://jakartaglobe.id/economy/aviationtycoon-susi-surprising-pick-jokosmaritime-affairs-minister/

Bax, S. (2011). Discourse and genre: Analysing language in context. Basingstoke: Palgrave Macmillan.

Breen, M. (1985). Authenticity in the language classroom. Applied Linguistics, 6, 6070.

Christ, C.P. (2016). A new definition of Patriarchy: Control of women's sexuality. Private Poverty, and War, 24(3), 214-225.

Cots, J.M. (2006). Teaching 'with an attitude': Critical discourse analysis in EFL teaching. ELT Journal, 60(4), 336-345.

Creswell, J.W. (2014). Research design: Qualitative, quantitative, and mixed methods approaches (4th ed.). London: Sage.

Eagleton, T. (1991). Ideology. London: Verso.

Faramarzi, S., Elekaei, A., \& Tabrizi, H.H. (2016). Critical thinking, autonomy, and lexical knowledge of Iranian EFL learners. Theory and Practice in Language Studies, 6(4), 878-885.

Fairclough, N. (1985). Critical and descriptive goals in discourse analysis. Journal of Pragmatics, 9, 739-763.

Fairclough, N. (1989). Language and power. London: Longman.

Fairclough, N. (1992a). Discourse and social change. Cambridge; Polity Press.

Fairclough, N. (1992b). Critical language awareness. Harlow: Longman.

Fairclough, N. (1992c). Introduction. In N. Fairclough (Ed.). Critical Language Awareness (pp. 1-29), London: Longman.

Fairclough, N. (1995). Media discourse. London: Edward Arnold.

Fairclough, N. (2003). Analysing discourse: Textual analysis for social research. London: Routledge.

Fairclough, N. (2013). Critical discourse analysis: The critical study of language (2nd ed.). Oxon: Routledge.

Fairclough, N. (2015). Language and power (3rd ed.). London: Routledge.

Fairclough, N., \& Wodak, R. (1997). Critical discourse analysis. In T.A. van Dijk (Ed.), Discourse as social interaction (pp. 258-284). London: Sage.

Flowerdew, J. (2013). Discourse in English language education. Oxon: Routledge.

Foucault, M. (1982). The subject and power. In H. Dreyfus \& P. Rabinow (Eds.), Beyond structuralism and hermeneutics (pp. 208-226). Chicago: University of Chicago Press.

Fowler, R. (1991). Language in the news. London: Routledge.

Fowler, R. (2013). Language in the news: Discourse and ideology in the press. London: Routledge.

Gee, J.P. (2011). An Introduction to discourse analysis: Theory and method (3rd ed.). London: Routledge.

Grabe, W. (2008). Reading in a second language moving from theory to practice (Cambridge applied linguistics). Cambridge: Cambridge University Press.

\footnotetext{
*Author(s) Correspondence:

E-mail: wsantoso@bundamulia.ac.id
} 
Harmer, J. (2007). How to teach English. Essex, UK: Pearson Education.

Haryanti, A., \& Suwana, F. (2014). The construction of feminism in Indonesian film: Arisan 2!'. Procedia - Social and Behavioral Sciences, 155, 236-241.

Hashemi, M.R., \& Ghanizadeh, A. (2012). Critical discourse analysis and critical thinking: An experimental study in an EFL context. System, 40, 37-47.

Hyde, M. (1994). The teaching of English in Morocco: The place of culture. ELT Journal, 48(4), 295-305.

Ida, R. (2001). The construction of gender identity in Indonesia: Between cultural norms, economic economic implications, and state formation. Masyarakat, Kebudayaan, dan Politik, 1, 21-34.

Janks, H. (1997). Critical discourse analysis as a research tool. Discourse: Studies in the cultural politics of education, 18(3), 329-342.

Jayanti, F.G., \& Norahmi, M. (2014). EFL: Revisiting ELT practices in Indonesia. Journal on English as a Foreign Language, 4(1), 5-14.

Jenkins, J. (2012). English as a Lingua Franca from the classroom to the classroom. ELT Journal, 66(4), 486-494.

Jeyaraj, J.J., \& Harland, T. (2014). Transforming teaching and learning in ELT through critical pedagogy: An international study. Journal of Transformative Education, 12(4), 343355.

Jones, E.P. (2007). Why there is no such thing as "critical discourse analysis". Language \& Communication, 27, 337368.

Karimi, L., \& Veisi, F. (2016). The impact of teaching critical thinking skills on reading comprehension of Iranian intermediate EFL learners. Theory and Practice in Language Studies, 6(9), 1869-1876.

Kilickaya, F. (2004). Authentic materials and cultural content in EFL classrooms, The Internet TESL Journal, 10(7).
Kim, K.H. (2014). Examining US news media discourses about North Korea: A corpus-based critical discourse analysis. Discourse \& Society, 25(2), 221-244.

Kirkpatrick, A. (2007). Teaching English across cultures: What do English language teachers need to know to know how to teach English?. EA Journal, 23(2), 20-36.

Kocatepe, M. (2005). Troubling essentialised contructions of cultures: An analysis of a critical discourse analysis approach to teaching and learning language and culture (Doctor thesis, James Cook University). Retrieved from https://researchonline.jcu.edu.au/1117/2/ 02whole.pdf

Larrain, J. (1979). The concept of ideology. London: Hutchinson.

Larson, K.R. (2014). Critical pedagogy(ies) for ELT in Indonesia. TEFLIN Journal, 25(1), 122-138.

Li, J. (2009). Intertextuality and national identity: Discourse of national conflicts in daily newspapers in the United States and China. Discourse \& Society, 2(1), $85-121$

Mambu, J.E. (2011). English for advocacy purposes: Critical pedagogy's contribution to Indonesia. The Journal of Asia TEFL, 8(4), 135-173.

Martin, J.R., \& Wodak, R. (2003). Re/reading the past: Critical and functional perspectives on time and value, Amsterdam: John Benjamins.

Maula, B.S. (2010). Women struggle on political rights in Indonesia: Social and religious studies on the failure of women's 30 percent quota in the Indonesian Parliament. Palastren, 3(1), $89-125$

McGregor, S.L.T. (2010). Critical discourse analysis: A primer. Halifax: Mount Saint Vincent University.

Mogashoa, T. (2014). Understanding critical discourse analysis in qualitative research. International Journal of Humanities Social Sciences and Education, 1(7), pp. 104-113.

*Author(s) Correspondence:

E-mail: wsantoso@bundamulia.ac.id 
Montiel, A.V. (2015). News media coverage of women. Asia Pacific Media Educator, 25(2), pp. 182-193.

Murtiningsih, B.S.E., \& Elmada, M.A.G. (2017). Representation of patriarchal culture in new media: A case study of news and advertisement on Tribunnews.com. Mediterranean Journal of Social Sciences, 8(3), 143154.

Neuman, S.B., Kaefer, T., \& Pinkham, A. (2014). Building background knowledge. The Reading Teacher, 68(2), 145-148.

Nilan, P., \& Dermatoto, A. (2012). Patriarchal residues in Indonesia: Respect accorded senior men by junior men. European Journal of Social Sciences, 31(2), 279293.

O'Keeffe, A., McCarthy, M., \& Carter, R. (2007). From corpus to classroom: Language use and language teaching. Cambridge: Cambridge University Press.

Rahimi, E., \& Sharififar, M. (2015). Critical discourse analysis and its implication in English language teaching: A case study of political text. Theory and Practice in Language Studies, 5(3), 504-511.

Richardson, J.E. (2007). Analysing newspapers: An approach from critical discourse analysis. Palgrave Macmillan: New York.

Risdaneva (2018). A critical discourse analysis of women's portrayal in news reporting of sexual violence. Studies in English Language and Education, 5(1), 126136.

Robson, C. (2013). Real world research (3rd ed.). Chichester: John Wiley \& Sons.

Salviana, V., \& Soedarwo, D. (2014). Political ideology meaning and patriarchal ideology of female politicians in Indonesia: A case in Malang. Procedia Environmental Sciences, 20, 486-495.

Sultana, A. (2011). Patriarchy and women's subordination: A theoretical analysis. The Arts Faculty Journal, 6(1), 1-18.

Susilo, D. (2017). Masculinity discourse on media text: A critical review about news about violence on online news portals. Masyarakat, Kebudayaan, dan Politik, 30(4), 344-352.

Tenorio, H.E. (2011). Critical discourse analysis: An overview. Nordic Journal of English Studies, 10(1), 183-210.

Thompson, J. B. (1984). Studies in the theory of ideology. Cambridge: Polity Press.

Thompson, J.B. (1990). Ideology and modern culture. Cambridge: Polity Press.

van Dijk, T.A. (1995). Aims of critical discourse analysis. Japanese Discourse, 1, 17-27.

van Dijk, T. A. (1998) Ideology: A Multidisciplinary Approach. London: Sage.

van Dijk, T.A. (2001). Critical discourse analysis. In D. Tannen, D. Schiffrin, \& H. Hamilton (Eds.), The handbook of discourse analysis (pp. 352-371). Oxford: Blackwell.

van Dijk, T. A. (2009). News, discourse, and ideology. In K. Wahl-Jogersen \& $\mathrm{T}$. Hanitzch (Eds.), The Handbook of Journalism Studies (pp. 191-204). New York: Routledge.

Wahjusaputri, S. (2015). Religion conflicts in Indonesia: Problems and solutions. Sociology Study, 5(12), 931-936.

Wang, X., \& Zheng, H. (2016). Reasoning critical thinking: Is it born or made?. Theory and Practice in Language Studies, 6, no. 6, 1323-1331.

Widdowson, H.G. (1995a). Discourse analysis: a critical view. Language and Literature, 4(3), 157-172.

Widdowson, H.G. (1995b). Norman Fairclough: "Discourse and social change" [Review of the book Discourse and social change, by N. Fairclough]. Applied Linguistics, 16(4), 510-516.

Widdowson, H.G. (2004). Text, context, pretext: Critical issues in discourse analysis. Oxford: Blackwell.

Wodak, R. (2001a). The discourse-historical approach. In R. Wodak \& M. Meyer (Eds.), Methods of critical discourse analysis (pp. 63-95), London: Sage.

Wodak, R. (2001b). What CDA is about- a summary of its history, important

*Author(s) Correspondence:

E-mail: wsantoso@bundamulia.ac.id 
concepts and its developments. In R. Wodak \& M. Meyer (Eds.). Methods of critical discourse analysis (pp. 1-13), London: Sage.

Wodak, R. (2002). Aspects of critical discourse analysis. Zeitschrift für Angewandte Linguistik, 36, pp. 3-31.

Wodak, R. (2011). Critical discourse analysis: Challenge, overview and perspectives. In G. Anderson \& K. Aijmer (Eds.), Pragmatics of society (pp. 627-650), Berlin: Mouton de Gruyter.

Wodak, R., \& Busch, B. (2004). Approaches to media texts. In J.H. Downing (Ed.), The Sage handbook of media studies (pp. 105-123). London: Sage.
Wodak, R., \& Ludwig, C.H. (1999). Challenges in a changing world: Issues in critical discourse analysis, Vienna: Passagenverlag.

Wodak, R., \& Meyer, M. (2009a). Methods of critical discourse analysis (2nd ed.). London: Sage.

Wodak, R., \& Meyer, M. (2009b). Critical discourse analysis: History, agenda, theory and Methodology. In R. Wodak \& M. Meyer (Eds.), Methods of Critical Discourse Analysis (pp. 1-33). London: Sage.

Zaid, M.A. (1999). Cultural confrontation and cultural acquisition in the EFL classroom. IRAL, 37(2), 111-126.

\section{APPENDIX 1 \\ A sample of task using CDA \\ Context:}

This task is for the undergraduate students, aged 20-22, in a private university in Indonesia. They have the intermediate level of English and are in the second semester. This activity is given to the students in the Critical Reading Class as part of a compulsory course in the English Education programme. This class particularly aims at developing the students' critical thinking in reading discourse such as newspapers, advertisements, political speech, and posters in order to reveal the underlying assumptions in discourse. This class is also a pre-requisite and preparation course for them to take Academic Reading class in the following semester.

\section{Skill:}

Reading (skimming and scanning). The students can use these reading strategies according to the types of questions asked. For example, the questions in the 'social practice' and 'discourse practice' require the students to use skimming, while the questions in the 'textual practice' require the students to use scanning. Nevertheless, these strategies can also be used concurrently depending on how the students use them to answer the questions.

\section{Aims:}

(1) to increase the students' awareness of social issues, i.e. gender, that exists in their surrounding and how such issues are presented in news articles.

(2) to give the students a view of how language is used by an author according to their goals and circumstances.

\section{Learning outcomes:}

At the end of the lesson, the students will be able to:

(1) Read strategically though skimming and scanning

(2) Evaluate critically the issues presented in the news article

(3) Classify words that have positive and negative meanings according to the context and how they are used.

\footnotetext{
*Author(s) Correspondence:

E-mail: wsantoso@bundamulia.ac.id
} 


\section{Reading task}

Pre-reading activity:

The students are asked to discuss their opinions towards Susi as the new maritime affairs ministers with their friends.

\section{The main activity:}

The students are asked to discuss and answer the following questions in a group of four by writing the answer in a piece of paper.

\section{Social practice}

1. In this article, is Susi described as having the capability of being the maritime affairs minister? Why?

2. How is Susi being portrayed in this article?

3. How is Indroyono being portrayed in this article?

4. What do you think of Susi after reading the text?

5. What do you think of the president's decision to choose Susi as the minister? Do you agree/disagree with his decision? Why?

\section{Discourse practice}

6. What kind of readers is it addressed to?

7. What is the 'point' of the text? What is the author trying to tell us?

8. What do you remember about Susi and Indroyono after reading the text?

\section{Textual practice}

9. Underline the words/ phrases (nouns, adjectives, verbs) that describe Susi's and Indroyono's educational background and work experience!

10. Look at the word 'surprising/surprise' in the article, do you think it has a positive meaning?

11. In general, what kind of impression towards Susi do the words/ phrases used give to you? Positive or negative? Why?

12. In general, what kind of impression towards Indroyono do the words/ phrases used give to you? Positive or negative? Why?

13. List some words used to describe Susi and Indroyono that have positive and negative meaning for you in the table below!

\begin{tabular}{|l|l|}
\hline Susi & \\
\hline Positive words & Negative words \\
\hline & \\
& \\
& \\
& \\
\hline
\end{tabular}

*Author(s) Correspondence:

E-mail: wsantoso@bundamulia.ac.id 


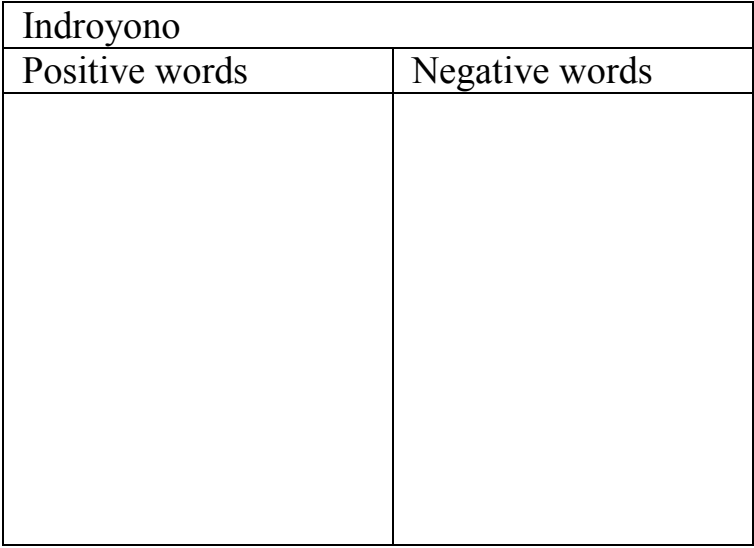

\section{Post-reading activity:}

There will be a whole-class discussion asking for 'what conclusions can you make after doing this activity?'

\section{APPENDIX 2}

The news text

Aviation Tycoon Susi a Surprising Pick as Joko's Maritime Affairs Minister

Jakarta. While President Joko Widodo's choice of Indroyono Soesilo as coordinating minister for maritime affairs was welcomed by the business community, the appointment of Susi Pudjiastuti as the minister of maritime affairs and fisheries was met with surprise in view of her apparent lack of any strong maritime background.

Susi, 49, owns aviation and lobster businesses.

"She was an entrepreneur who started her business from scratch, successful in her aviation business that is integrated with the maritime industry," Joko said when introducing Susi outside the State Palace on Sunday.

Susi is a senior high school dropout who started her business as a brokerage buying fish from fishermen in Pangandaran, West Java, in 1983.

Her company ASI Pudjiastuti Marine Products owns a fish processing facility and sells lobsters under the "Susi Brand" label.

Susi expanded into the aviation business in 2004 and her ASI Pudjiastuti Aviation, which runs the Susi Air airline, has managed to find a niche market by flying to remote regions that are not serviced by larger commercial airlines.

However, her business background does not impress Jeffrosenberg Tan, portfolio manager at Sinar Mas Asset Management, an asset management arm of the Sinar Mas Group.

*Author(s) Correspondence:

E-mail: wsantoso@bundamulia.ac.id 
"Is that the right person in the right place? It is just quite surprising, but there is no need for any negative comments for now. She may perform, let's give her some time," he said.

Jeffrosenberg expressed confidence over the appointment of Indroyono, given his strong background in the maritime sector.

Indroyono, who earned his Ph.D. in geologic remote sensing at the University of Iowa in the United States in 1987 , has a long list of experience in the government and international organizations.

Indroyono was the first Indonesian to occupy a high-level position in the Food and Agricultural Organization. He was the director of the fisheries and aquaculture resources use and conservation division at the FAO headquarters in Rome.

He also has experience in high-level positions in the office of the coordinating minister for people's welfare and the former ministry of sea exploration and fisheries.

Joko has repeatedly emphasized the maritime sector as the centerpiece of his policy platform. Indonesia's marine area comprises nearly eight million square kilometers, or about four times the country's land size. The nation has not yet fully taken advantage of its geographical assets.

*Author(s) Correspondence:

E-mail: wsantoso@bundamulia.ac.id 